\title{
FY98 Status Report on the HSV
}

by

K. L. Shanahan

Westinghouse Savannah River Company

Savannah River Site

Aiken, South Carolina 29808

DOE Contract No. DE-AC09-96SR18500

This paper was prepared in connection with work done under the above contract number with the U.S.

Department of Energy. By acceptance of this paper, the publisher and/or recipient acknowledges the U. S. Government's right to retain a nonexclusive, royalty-free license in and to any copyright covering this paper, along with the right to reproduce and to authorize others to reproduce all or part of the copyrighted paper. 


\title{
FY98 Status Report on the HSV (U)
}

\author{
Kirk L. Shanahan
}

September, 1998

Westinghouse Savannah River Company Savannah River Technology Center

Aiken, SC 29808

Prepared for the U.S. Department of Energy under Contract DE-AC09-96SR18500 


\section{DISCLAIMER}

This report was prepared as an account of work sponsored by an agency of the United States Government. Neither the United States Government nor any agency thereof, nor any of their employees, makes any warranty, express or implied, or assumes any legal liability or responsibility for the accuracy, completeness, or usefulness of any information, apparatus, product, or process disclosed, or represents that its use would not infringe privately owned rights. Reference herein to any specific commercial product, process, or service by trade name, trademark, manufacturer, or otherwise does not necessarily constitute or imply its endorsement, recommendation, or favoring by the United States Government or any agency thereof. The views and opinions of authors expressed herein do not necessarily state or reflect those of the United States Government or any agency thereof.

This report has been reproduced directly from the best available copy.

Available to DOE and DOE contractors from the Office of Scientific and Technical Information, P.O. Box 62, Oak Ridge, TN 37831; prices available from (615) 576-8401.

Available to the public from the National Technical Information Service, U.S. Department of Commerce, 5285 Port Royal Road, Springfield, VA 22161. 


\section{DISCLAIMER}

Portions of this document may be illegible in electronic image products. Images are produced from the best available original document. 
WSRC-TR-98-00353

Keywords:

Tritium

Titanium

HSV

Retention:

Permanent

\section{FY98 Status Report on the HSV (U)}

By

Kirk L. Shanahan

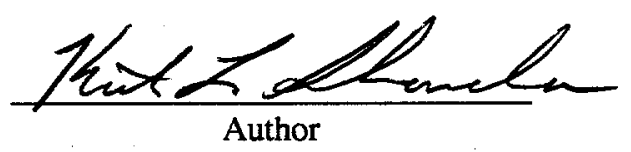

ISSUED: September, 1998

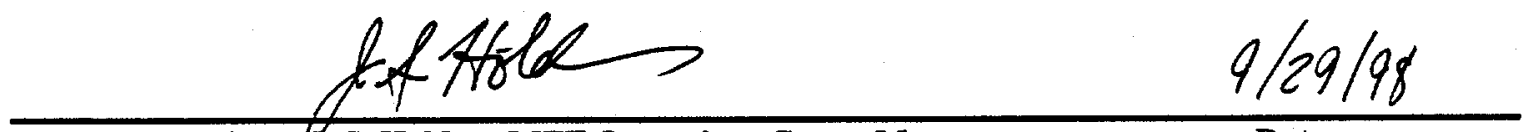

Technical Review: Y. S. Holder, MTF Operations Group Manager

Date:

SRTC Savannah River Technology Center, Aiken, SC 29808 Westinghouse Savannah River Company Prepared for the U. S. Department of Energy under Contract DE-AC09-96SR18500 
WSRC-TR-98-00353

\section{FY 98 Status Report on the HSV (U)}

\section{Kirk L. Shanahan}

\section{Summary}

The HSV in storage in MTF has been monitored during FY98, and its overpressure has been sampled and analyzed. The HSV's internal pressure continues to rise slowly, and the overpressure still analyzes as $100 \%{ }^{3} \mathrm{He}$. The titanium tritide sample that was to be monitored annually developed a leak during isotherm measurements, so isotherm data will be presented in the next report. However, it also had its pressure monitored and overpressure analyzed, and it appears to be showing ${ }^{3} \mathrm{He}$ release.

\section{Part 1. The Hydrogen Storage Vessel}

The first loaded HSV, HSV-002, was loaded on April 3, 1996 and delivered to the MTF where it was installed on a monitoring manifold. The HSV's temperature and pressure have been monitored since that time. A plot of the raw pressure data is shown in Figure 1. In general a linear increase in pressure is observed with time. While a pressure increase is measurable, the amount of gas represents much less than $1 \%$ of the total ${ }^{3} \mathrm{He}$ produced by decay inside the HSV. The overpressure sample was analyzed and contains $99.92 \%{ }^{3} \mathrm{He}$, with some traces of all three hydrogen isotopes detected (which may well have been contaminants originating in the sample vessel walls).

The plot has two problem points indicated. The first is a period where no monitoring was possible due to a thermocouple vacuum gauge failure during last year's overpressure sampling. Due to the sampling procedure, the HSV had to remain valved off from the manifold while the TCVG was replaced.

The second problem point occurred when a steam outage in building 232-H produced condensation on HVAC ducts. Which then dripped into the Baratron pressure sensor's electronics unit. This has apparently caused both an increase in noise level and a baseline shift. We are in the process of 
replacing the Baratron, and if the subsequent data continues the prior linear trend, the spurious data will be eliminated from next year's report.

The data shown, neglecting the last period of apparently spurious data, fit a straight line well. The fit parameters are: slope $=.0162(.0002)$, intercept $=$ $12.1(.08), \mathrm{R}^{2}=.9913$ (implying a linear correlation coefficient of .995$), \mathrm{F}=$ 10,400, st. dev. of regression $=.34$.

\section{Part 2. The Titanium Tritide Samples}

Nine titanium tritide samples were originally prepared with varying tritium and deuterium loadings for long term storage behavior studies. One sample has been used to collect pure tritium isotherm data on an annual basis. Reexamination of this sample was attempted this year, but has been interrupted because of a leak. (The most likely point for this to occur is the valve attached directly to the sample.) The Ti-3 overpressure was sampled and analyzed and found to be $99.962 \%{ }^{3} \mathrm{He}$, with no detectable hydrogen isotopes. This correlates well with the HSV analysis.

Unfortunately, the annual isotherm acquisition has been delayed because the sample cell began leaking during the determination. We are in the process of determining if the sample can be recovered, or if another sample will have to be utilized instead. An annual isotherm for this year will be reported in the next year's report if possible

However, one significant observation on this sample has been made. The overpressure for Ti3 has begun to rise with time. This is shown in Figure 2. Plotted are the available pressure data from the attached sensor on the Ti-3 sample, and two points where the overpressure has been calculated from the grab sampling process. As can be seen, during the preceding year the sample has begun to offgas. Calculated pressure inside the cell at the grab sampling point of Sept. 8, 1998 was 234.2 torr. This represents about $4.4 \%$ of the total ${ }^{3} \mathrm{He}$ produced during the last year by tritium decay (which is a typical value observed in other hydride materials).

The cause of this release is unknown at this time. Those other titanium tritide samples with attached pressure sensors do not show similar behavior. There are several possible explanations for the release. We could be observing true ${ }^{3} \mathrm{He}$ saturation or sample alteration due to the treatments experienced in the experimental studies (such as decrepitation which would 
radically increase the surface-to-volume ratio or alloying with the stainless steel sample vessel).

Ti-3 is an accelerated aging sample designed to age approximately twice as fast as the HSV. Upcoming studies will hopefully shed more light on this observation. 
Figure 1. Uncorrected HSV-002 Dverpressure

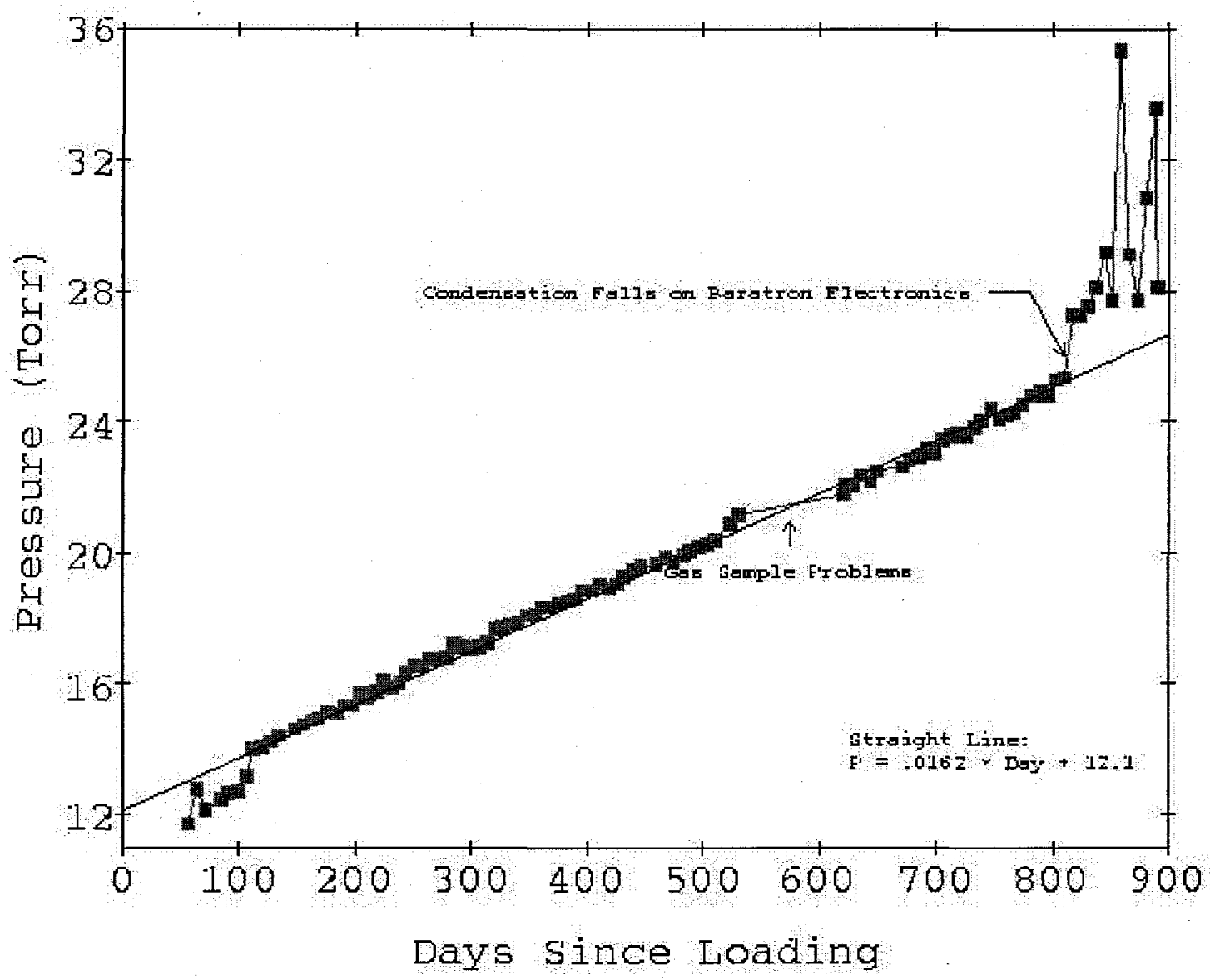


Figure 2. Ti-3 cell Pressure with Time

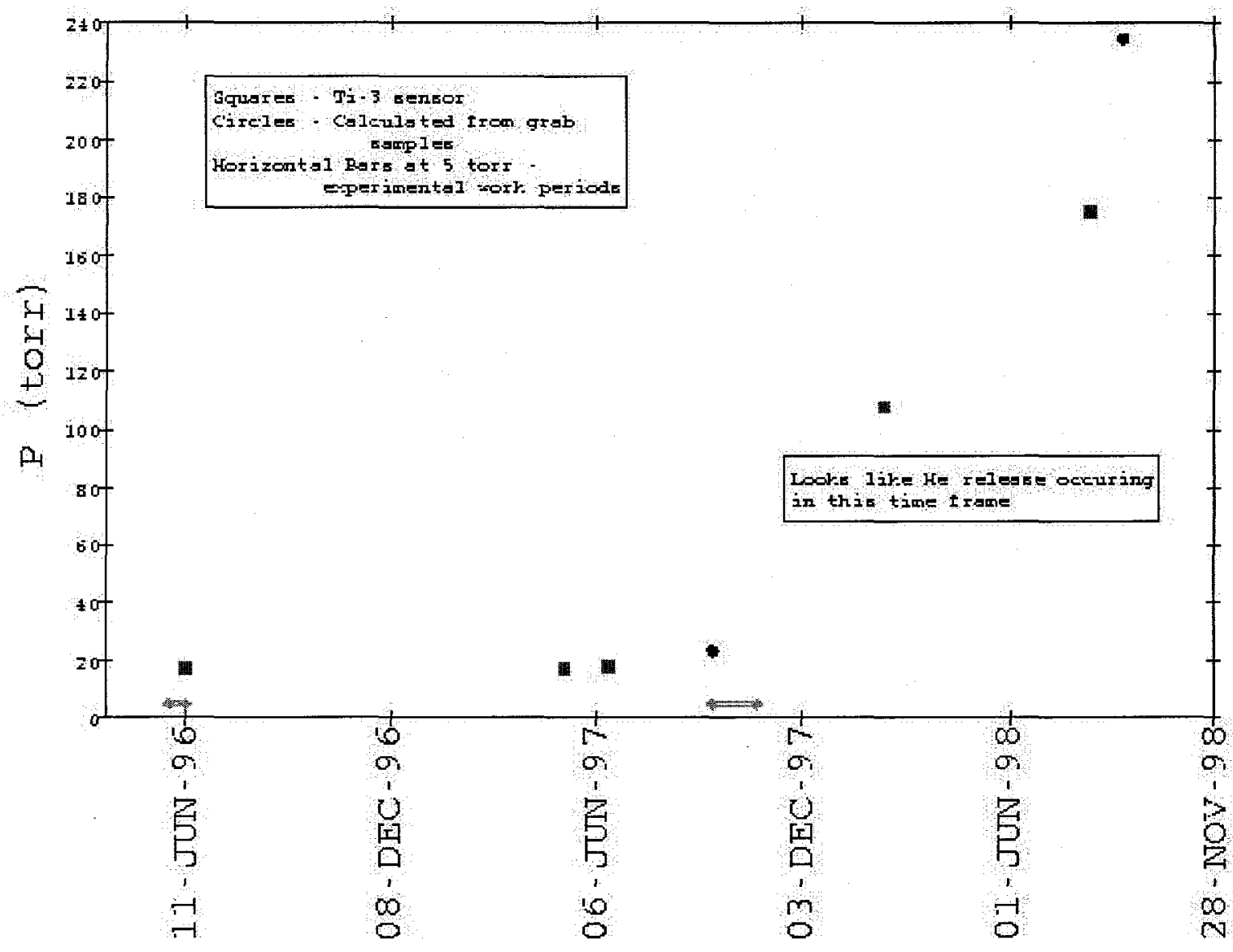


Figure 1. Uncorrected HSV-002 Overpressure

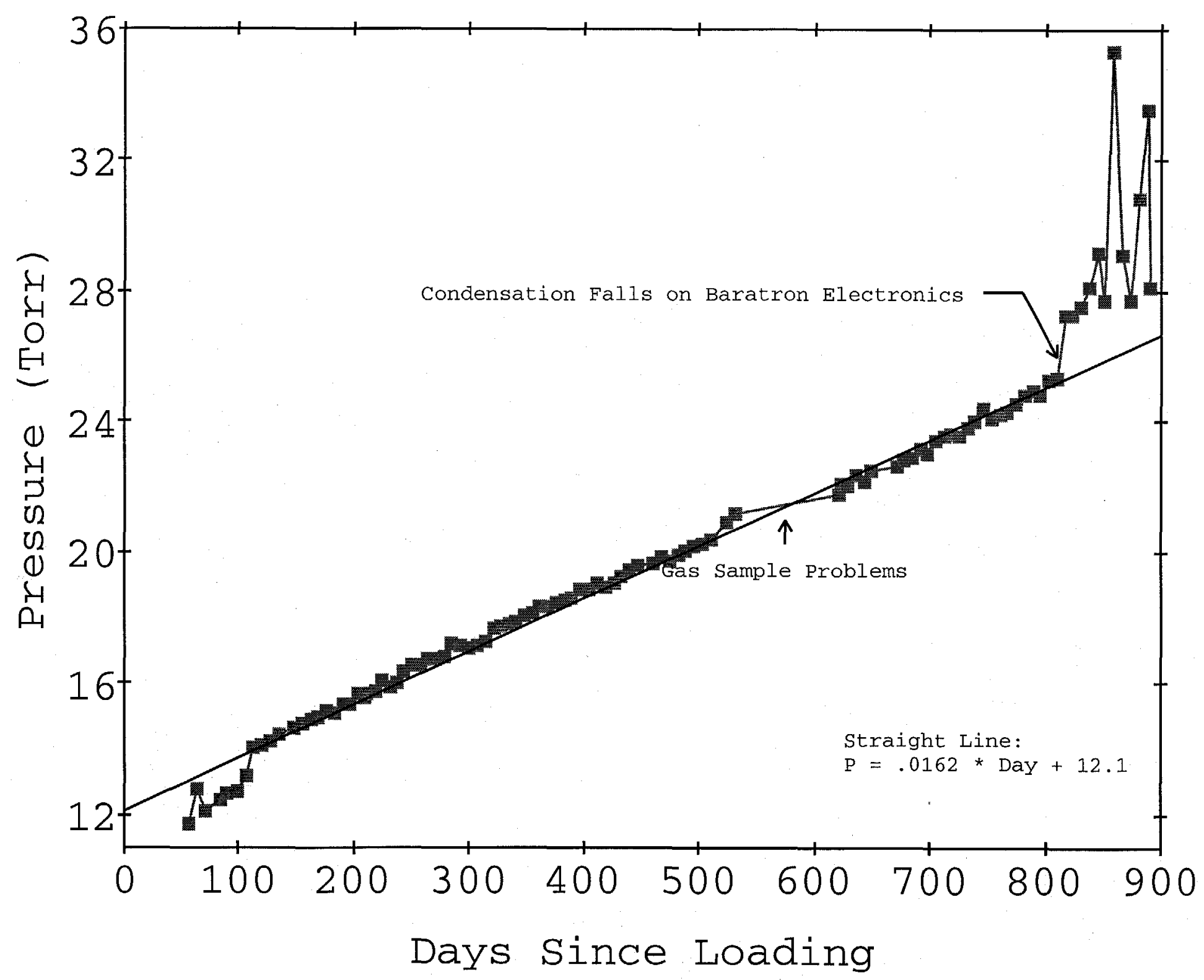


Figure 2. Ti-3 Cell Pressure with Time

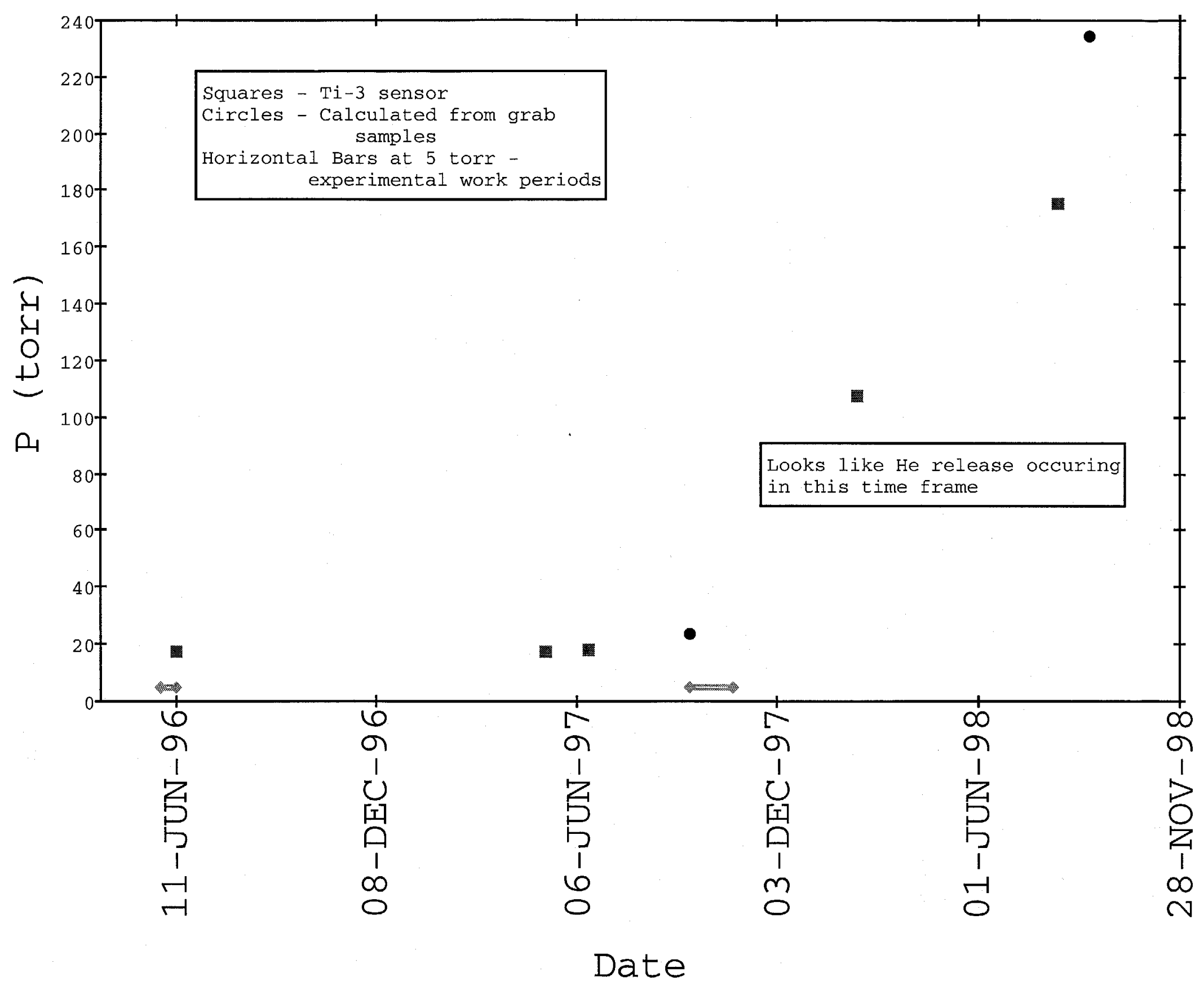

